\title{
Behaviour of a SPD Switchable Glazing in an Outdoor Test Cell With Heat Removal Under Varying Weather Conditions
}

Aritra Ghosh

Technological University Dublin, D11126937@mydit.ie

Brian Norton

Technological University Dublin, brian.norton@tudublin.ie

Aidan Duffy

Technological University Dublin, aidan.duffy@tudublin.ie

Follow this and additional works at: https://arrow.tudublin.ie/engschcivart

Part of the Energy Systems Commons

\section{Recommended Citation}

Ghosh, A., Norton, B. and Duffy, A. (2016) Behaviour of a SPD switchable glazing in an outdoor test cell with heat removal under varying weather conditions. Applied energy, Vol. 180, Oct. 2016, pp 695-706. doi:10.1016/j.apenergy.2016.08.029

This Article is brought to you for free and open access by the School of Civil and Structural Engineering at ARROW@TU Dublin. It has been accepted for inclusion in Articles by an authorized administrator of ARROW@TU Dublin. For more information, please contact arrow.admin@tudublin.ie, aisling.coyne@tudublin.ie, gerard.connolly@tudublin.ie.

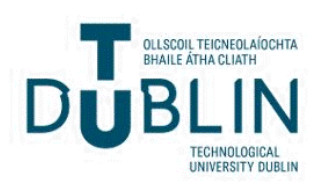




\title{
Behaviour of a SPD switchable glazing in an outdoor test cell with heat removal under varying weather conditions
}

\author{
Aritra Ghosh*, Brian Norton, Aidan Duffy \\ Dublin Energy Lab, Dublin Institute of Technology, Dublin, Ireland
}

\section{A R T I C L E IN F O}

Article history:

Received 4 May 2016

Received in revised form 3 August 2016

Accepted 4 August 2016

Available online xxx

\section{Keywords:}

Glazing

SPD

SHGC

Cooling load

Test cell

\section{A B S T R A C T}

Suspended particle device (SPD) switchable glazing has potential to control transmission of solar radiation in the visible range by changing its transparency from 55\% to 5\%. Outdoor test cell characterisation of a SPD switchable glazing offered the dynamic solar heat gain coefficient (SHGC) which varied between 0.05 (when opaque) and 0.38 (when transparent). Reduction of maximum temperature rise of $11 \%$ and $15 \%$ was possible using SPD "transparent" and "opaque" state compared to same area double-glazing. Insulated test cell with water flow heat exchanger was employed to measure the cooling load reduction potential of SPD glazing while its transmission changed from "transparent" to "opaque" state. A cooling load reduction up to $6 \mathrm{~kW}$ h for a $0.343 \mathrm{~m}^{3}$ volume test cell was possible by changing a $0.21 \mathrm{~m} \times 0.28 \mathrm{~m}$ SPD glazing transparency from "transparent" to "opaque". Average overall heat transfer coefficient of SPD glazing varied between $5.02 \mathrm{~W} / \mathrm{m}^{2} \mathrm{~K}$ and $5.2 \mathrm{~W} / \mathrm{m}^{2} \mathrm{~K}$ for two different states.

(C) 2016 Published by Elsevier Ltd

\section{Nomenclature}

A

$A_{g}$

$\mathrm{A}_{\mathrm{i}}$

$A_{\text {wall }}$

$\mathrm{C}_{\text {tc }}$

$\mathrm{C}_{\mathrm{g}}$

$\mathrm{h}_{0}$

$\mathrm{h}_{\mathrm{i}}$

I

$\mathrm{I}_{\text {beam,h }}$

$\mathrm{I}_{\text {dif,h }}$

$\mathrm{I}_{\text {extra }}$

$\mathrm{I}_{\mathrm{sc}}$

$\mathrm{k}_{\mathrm{d}}$

$\mathrm{k}_{\mathrm{g}}$

$\mathrm{k}_{\mathrm{T}}$

$\mathrm{K}_{\mathrm{pl}}$

$\mathrm{K}_{\text {wd }}$

$\mathrm{L}_{\mathrm{pl}}$

$\mathrm{L}_{\text {wd }}$

$1_{\mathrm{h}}$ cross sectional area of heat exchanger tube $\left(\mathrm{m}^{2}\right)$ aperture area of glazing $\left(\mathrm{m}^{2}\right)$ anisotropy index interior wall surface area $\left(\mathrm{m}^{2}\right)$ heat capacity of air $(\mathrm{kJ} / \mathrm{kg} \mathrm{K})$ heat capacity of water $(\mathrm{kJ} / \mathrm{kg} \mathrm{K})$

heat transfer coefficient from test cell external surface to ambient $\left(\mathrm{W} / \mathrm{m}^{2} \mathrm{~K}\right)$

heat transfer coefficient from test cell internal surface to interior of test cell $\left(\mathrm{W} / \mathrm{m}^{2} \mathrm{~K}\right)$

incident solar radiation on the vertical surface of glazing $\left(\mathrm{W} / \mathrm{m}^{2}\right)$

incident beam solar radiation on the horizontal surface $\left(\mathrm{W} / \mathrm{m}^{2}\right)$

incident diffuse solar radiation on the horizontal surface $\left(\mathrm{W} / \mathrm{m}^{2}\right)$

incident extra-terrestrial solar radiation $\left(\mathrm{W} / \mathrm{m}^{2}\right)$

solar constant $\left(\mathrm{W} / \mathrm{m}^{2}\right)$

diffuse factor

extinction coefficient

clearness index

thermal conductivity of polystyrene $(\mathrm{W} / \mathrm{m} \mathrm{K})$

thermal conductivity of wood $(\mathrm{W} / \mathrm{m} \mathrm{K})$

thickness of polystyrene (m)

thickness of wood (m)

length of heat exchanger pipe (m)

\footnotetext{
* Corresponding author.

Email address: aritra.ghosh@mydit.ie (A. Ghosh)
}

$\mathrm{M}_{\mathrm{tc}}$
$\dot{m}$
$\mathrm{~N}_{\mathrm{g}}$
$\mathrm{n}$
$\mathrm{Q}_{\mathrm{in}}$
$\mathrm{Q}_{\mathrm{tc}}$
$\mathrm{Q}_{\mathrm{g}}$
$\mathrm{Q}_{\mathrm{loss}}$
$\mathrm{r}_{\mathrm{h}}$
$\mathrm{SE}_{\mathrm{SPD}}$
$\mathrm{T}_{\mathrm{tc}, \text { in }}$
$\mathrm{T}_{\mathrm{a}}$
$\mathrm{U}_{\mathrm{g}}$

mass of the air inside test cell $(\mathrm{kg})$

mass flow rate of water $(\mathrm{kg} / \mathrm{s})$

number of glass pane

refractive index

total energy incident on the glazing (W)

total energy available inside the test cell (W)

heat through the glazing Incident solar radiation (W)

heat loss through the surfaces of test cell (W)

radius of heat exchanger pipe $(\mathrm{m})$

transmitted solar energy through SPD glazing $\left(\mathrm{W} / \mathrm{m}^{2}\right)$

interior temperature $\left({ }^{\circ} \mathrm{C}\right)$

ambient temperature $\left({ }^{\circ} \mathrm{C}\right)$

overall heat transfer coefficient of glazing $\left(\mathrm{W} / \mathrm{m}^{2} \mathrm{~K}\right)$

\section{Greek symbols}

$\alpha$

transmittance

$\tau_{\mathrm{v}} \quad$ vertical global transmittance

$\tau_{\text {dir }} \quad$ direct transmittance

$\tau_{\text {diff }} \quad$ diffuse transmittance

$\theta \quad$ incidence angle

\section{Introduction}

Building consumes around $30-40 \%$ of the world primary energy consumption for heating, ventilation, and cooling systems to enhance indoor thermal comfort $[1,2]$. To reduce the greenhouse gas emission and energy consumption from fossil fuel, it is necessary to improve the energy efficiency of building cooling systems. Admitted solar radiation through glazed building envelope increases a major portion of 
the total cooling load [3]. To avoid overheating by solar gain due to solar radiation, a building can (i) have small solar aperture [4], (ii) have high thermal mass or other heat sinks [4], (iii) have an appropriately coated glazing [4], (iv) have high natural ventilation rates [4], (v) include blinds at windows, (vi) include switchable glazing to give variable control solar gain through glazing [5-10], (vii) include forced circulation heat removal by air [11-13] or water flow [14-17] on the glazing's outside surface or between the two glass panes.

In a water flow glazing, water acts as an antireflection coating that absorbs short wave radiation but does not reduce the transparency of the glazing $[18,19]$. Water flow with double-glazing was found to maintain room temperature between 18 and $20^{\circ} \mathrm{C}$ [20,21]. Water flow windows can potentially control the heat gain by $32 \%$ and $52 \%$ compared to double and single glazing respectively $[14,16]$. Water flow or airflow windows however need maintenance, controls, actuator, and pumps or fans.

Control of solar heat gain is also possible using a switchable glazing that changes opacity to restrict solar heat gain. Available switchable glazings are either (i) electrically controllable including electrochromic (EC) [22-25], liquid crystal (LC) [26-28], suspended particle device (SPD) [29-36] or (ii) not controllable but rather switch state when specific conditions are present, these include gasochrormic [37-41], thermochromic [42-44], thermotropic [45,46] and phase change material [47-53].

Electrochromic glazing uses direct current (DC) to power switching whereas LC and SPD use alternating current (AC). An EC glazing changes from transparent to opaque by redox reaction in the presence of applied DC voltage typically from 0 to $5 \mathrm{~V}$ [54] that is reversed by inversion of electrical polarity $[55,56]$. Switching speed of colouration process for EC material is slow, increasing with the area of device, and affected by environmental conditions [57-59]. Switching time of EC glazing is proportional to the square root of the active glazing area. EC colouration process (due to switching) does not always ensue evenly over large glazed areas[60,61].

In case of LC glazing, LC particles inside polymer mixtures are sandwiched between two glass panes [27,62]. In the presence of an electric field, liquid crystals align parallel to the field enabling light to pass through, creating a transparent state. The switch between the two states is nearly instantaneous. LC glazings have a hazy appearance as they scatter rather than absorb light [63].

In an SPD glazing, an SPD material is sandwiched between two glass panes. Without applied voltage, particles are suspended randomly and block light. Upon application of AC supply, particles are aligned perpendicularly to the charged plates $[32,64]$ to pass light as shown in Fig. 1. The window changes its transmission from 5\% to $55 \%$ in the presence of $0-110 \mathrm{~V}$ AC supply while switching speed is only few 100-120 ms [35]. SPD glazing also possess variable transparency under variable applied voltage [34]. Overall heat transfer coefficient ( $U$-value) of this SPD glazing has been found to be $5.9 \mathrm{~W} /$ $\mathrm{m}^{2} \mathrm{~K}$ using a thermally insulated test cell [32]. Low heat loss switchable SPD glazing offered a low overall heat loss coefficient, which varied between 1.00 and $1.16 \mathrm{~W} / \mathrm{m}^{2} \mathrm{~K}$ [33]. It was also found that SPD glazing is a suitable candidate to control the indoor daylight level and glare [34]. SPD glazing was powered from renewable source (photovoltaic device) and found to be a potential combination for future low energy building application where SPD will reduce the building energy demand and PV will generate supply to power the glazing [35]. Thus, SPD glazing can be considered as a potential candidate for zero energy or retrofit building application due to its glare control potential, variable transparency, and ability to switch with PV device. Investigation of SPD glazing is required to find out its solar gain control potential, which enhances the reduction of cooling load demand.

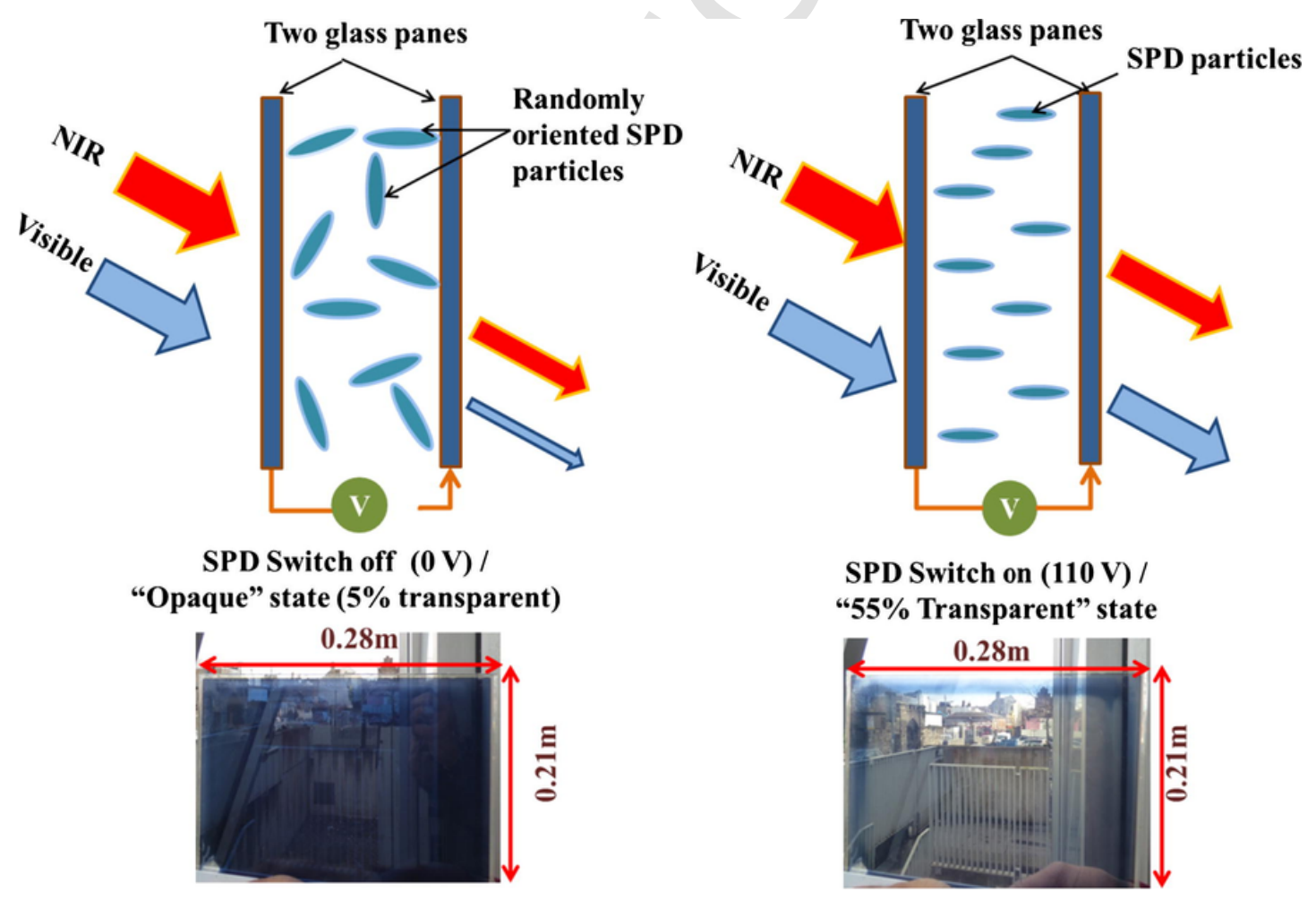

Fig. 1. SPD glazing switching showing (a) "opaque" and (b) "transparent" state. 
Buildings experience diurnal solar gain due to diurnal variation of solar radiation. This variable gain can be controlled by varying transparency of switchable SPD glazing. The variable solar heat gain coefficient (SHGC) can enhance the occupant comfort by changing the states of the glazing. Up to date, no characterisation was reported to find the dynamic SHGC and cooling load reduction potential for switchable transmission of SPD glazing.

The aims of this research were to investigate

- the dynamic SHGC for SPD glazing;

- the reduction of cooling load provided by the transition of the SPD from "transparent" to "opaque" states;

- the overall heat transfer coefficient ( $U$-value) of SPD glazing and double-glazing by heat removal (water flow heat exchanger) process from test cell.

Results of this work will be beneficial for building engineers to incorporate in retrofit or design a new low energy building with SPD switchable glazing.

\section{Methodology}

Outdoor test cell is an appropriate apparatus for the dynamic performance evaluation [65-68] for glazings. In this experiment, a test cell was equipped with a water flow heat exchanger to maintain the test cell temperature at a human comfort level. Heat exchangers were used to extract heat by using fluid flow [69-73] in many applications in the field of solar energy [73-83]. Water was used inside the heat exchanger as it has a high heat capacity [84] that enable to control the inside temperature.

\subsection{System description}

Two identical $0.7 \mathrm{~m}$ wide, $0.7 \mathrm{~m}$ deep and $0.7 \mathrm{~m}$ high test cells were insulated with inside surfaces composed of $0.10 \mathrm{~m}$ thick polystyrene material [32-35]. The active area of both SPD glazing and double-glazing was $0.0588 \mathrm{~m}^{2}$ as shown in Fig. 2. The ratio of south facing test cell and glazing area was $8: 1.0 .45 \mathrm{~m}$ long and $0.05 \mathrm{~m}$ diameter copper coil heat exchangers pipe was placed for both test cells. Water flow was controlled using ultrasonic flow meter.

Heat gains through the test glazing were balanced by the energy extracted by the heat exchanger of the test cell. The inside temperature was controlled by maintaining the inlet temperature of the circulating water through the heat exchanger at a constant mass flow rate of $0.016 \mathrm{~kg} / \mathrm{s}$. The temperature rise and the mass flow rate of the fluid across the heat exchanger were measured and the amount of energy lost by the heat exchanger was calculated.

Vertical plane pyranometer and horizontal plane pyranometer were set up to measure the solar radiation. Ambient, test cell internal ambient, internal, and external surface of glazing, water flow inlet and outlet temperature were measured using T type thermocouples. Delta $\mathrm{T}$ type data logger was employed in this experiment to record the continuous data. Fig. 3 illustrates the complete photographic view of experimental set up.

\subsection{Glazing transmission}

Measured transmission spectra for SPD glazing in "opaque" and "transparent" states and for double-glazing using AvaSpec-ULS2048L Star Line Versatile Fiber-optic Spectrometer is shown in Fig. 4.

Absorption of SPD glazing was calculated using Eq. (1) where reflection was calculated using Fresnel equation given by Eq. (2) [85].

$$
A_{s p d}=1-\left(T_{s p d}+R_{s p d}\right)
$$

$$
R_{s p d}=\left(\frac{n_{g}-n_{\text {air }}}{n_{g}+n_{\text {air }}}\right)^{2}
$$

where the refractive indices of SPD glazing $\left(\mathrm{n}_{\mathrm{g}}\right)$ and air $\left(\mathrm{n}_{\text {air }}\right)$ are 1.6 and 1.0 respectively. The solar absorption for different glazings are described in Table 1.

\section{Calculations of glazing properties}

\subsection{Dynamic solar heat gain coefficients}

For vertical surface glazing, direct solar radiation incident to the glazing surface at oblique incidence angles at which the transmittance is different from the near-normal values. This angular behaviour of $\tau_{v}$ (global solar transmittance through glazing) was calculated from as [86] as given in Eq. (3).

$$
\begin{aligned}
\tau_{v}= & {\left[k_{d}\left\{k_{T} R_{b}\left(1-k_{d}\right)+(1-\cos \beta)\left(1-k_{T}\left(1-k_{d}\right)\right)\right\}\right.} \\
& \left.+R_{b}\left(1-k_{d}\right)+R_{g} \frac{1-\cos \beta}{2}\right] \times \tau_{d i r} R_{b}\left(1-k_{d}\right)\left(1+k_{d} k_{T}\right) \\
& +\frac{\tau_{d i f} k_{d}}{2}(1+\cos \beta)\left(1-k_{T}\left(1-k_{d}\right)\right)+\frac{\tau_{g} R_{g}(1-\cos \beta)}{2}
\end{aligned}
$$

$$
\begin{aligned}
\tau=\frac{1}{2}\left[\frac{1-\left\{\frac{\sin (\theta-n)}{\sin (\theta+n)}\right\}^{2}}{1+\left(2 n_{g}-1\right)\left\{\frac{\sin (\theta-n)}{\sin (\theta+n)}\right\}}\right. \\
\left.+\frac{1-\left\{\frac{\tan (\theta-n)}{\tan (\theta+n)}\right\}^{2}}{1+\left(2 n_{g}-1\right)\left[\frac{\tan (\theta-n)}{\tan (\theta+n)}\right]^{2}}\right] \times \exp \left(\frac{-k_{g} N_{g} t_{g}}{\cos \theta}\right)
\end{aligned}
$$

and

$$
\begin{aligned}
& \tau=\tau_{d i r} \text { when } \theta=\theta_{d i r} \\
& \tau=\tau_{d i f} \text { when } \theta=\theta_{d i f}=59.68-0.1388 \beta+0.001497 \beta^{2}[87] \\
& \tau=\tau_{g} \text { when } \theta=\theta_{g}=90-0.5788 \beta+0.002693 \beta^{2}[87]
\end{aligned}
$$

Diffuse factor $\left(\mathrm{k}_{\mathrm{d}}\right)$ and clearness index $\left(\mathrm{k}_{\mathrm{T}}\right)$ can be calculated by using Eqs. (5) and (6).

$$
k_{d}=\frac{I_{d i f, h}}{I_{\text {global }}}
$$

$$
k_{T}=\frac{I_{\text {global }}}{I_{\text {extra }}}
$$

where 


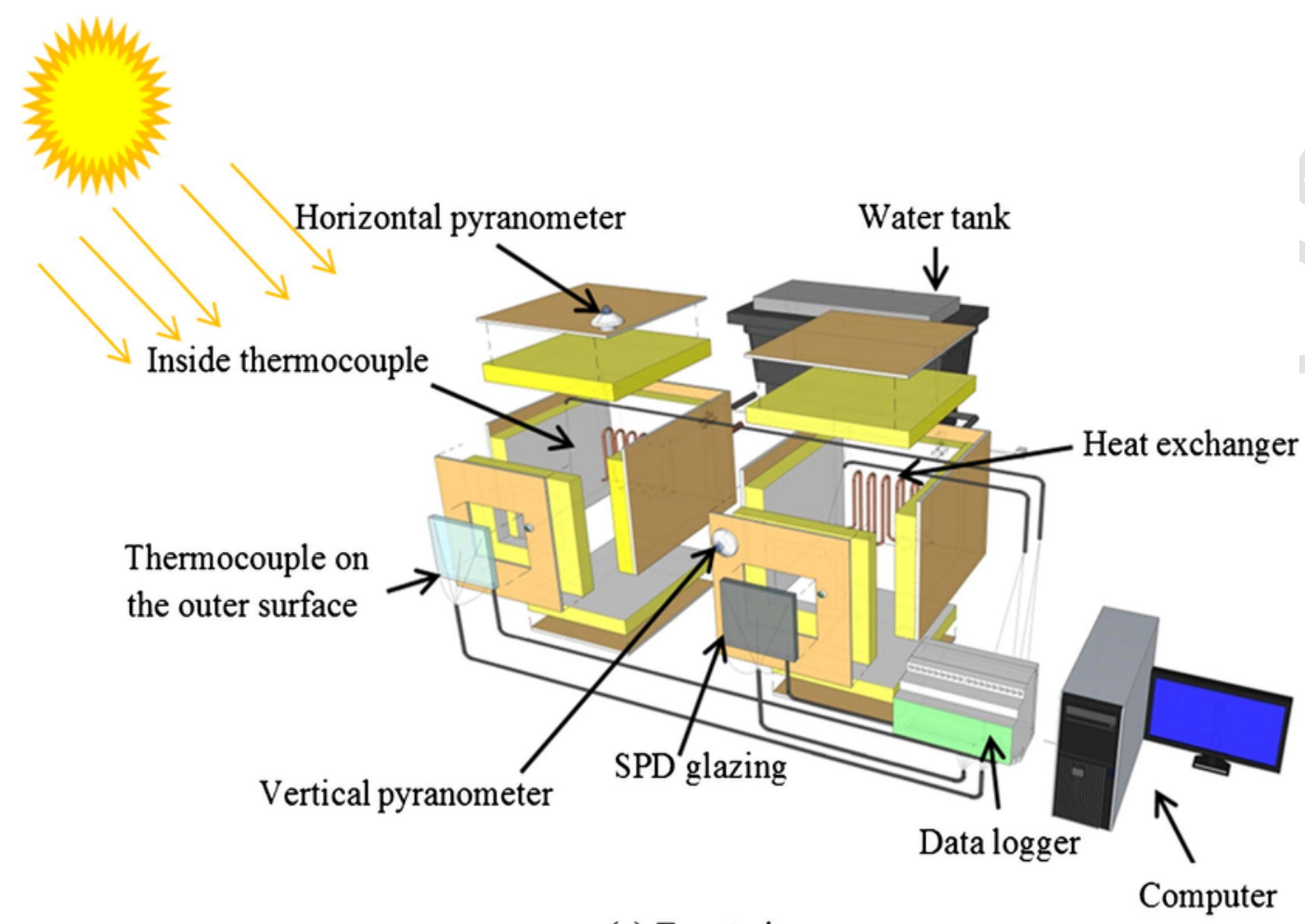

(a) Front view

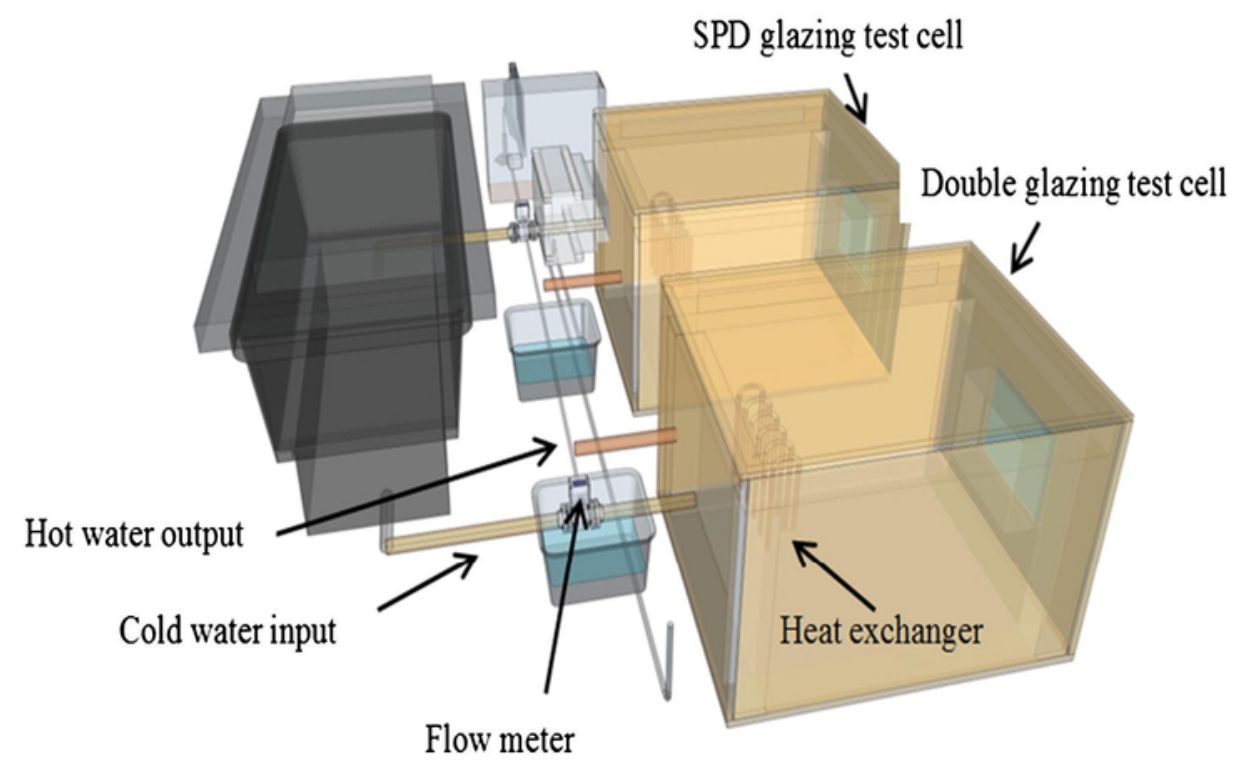

(b) Rear view

Fig. 2. Experimental set up.

$I_{\text {extra }}=I_{s c}\left(1+0.033 \cos \frac{360 n}{365}\right)(\cos \phi \cos \delta \cos \omega$

$$
+\sin \phi \sin \delta)
$$

$I_{s c}$ is the solar constant, $\mathrm{n}$ is the day of year, $\phi$ latitude angle, $\delta$ declination angle and $\omega$ hour angle.

Solar energy transmitted through glazing [86] can be written as Eq.

(8) 


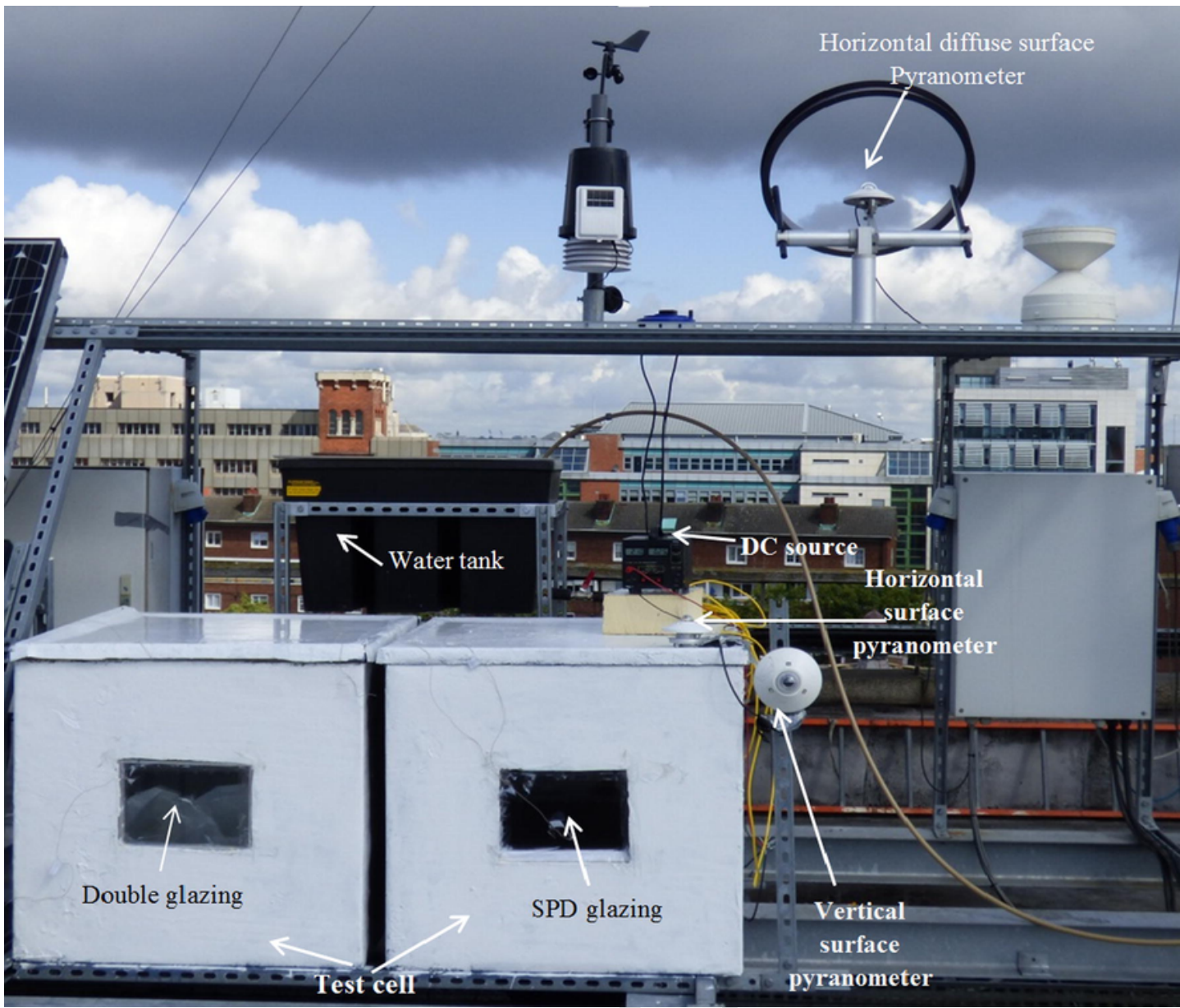

Fig. 3. Photographic view of experimental set up.

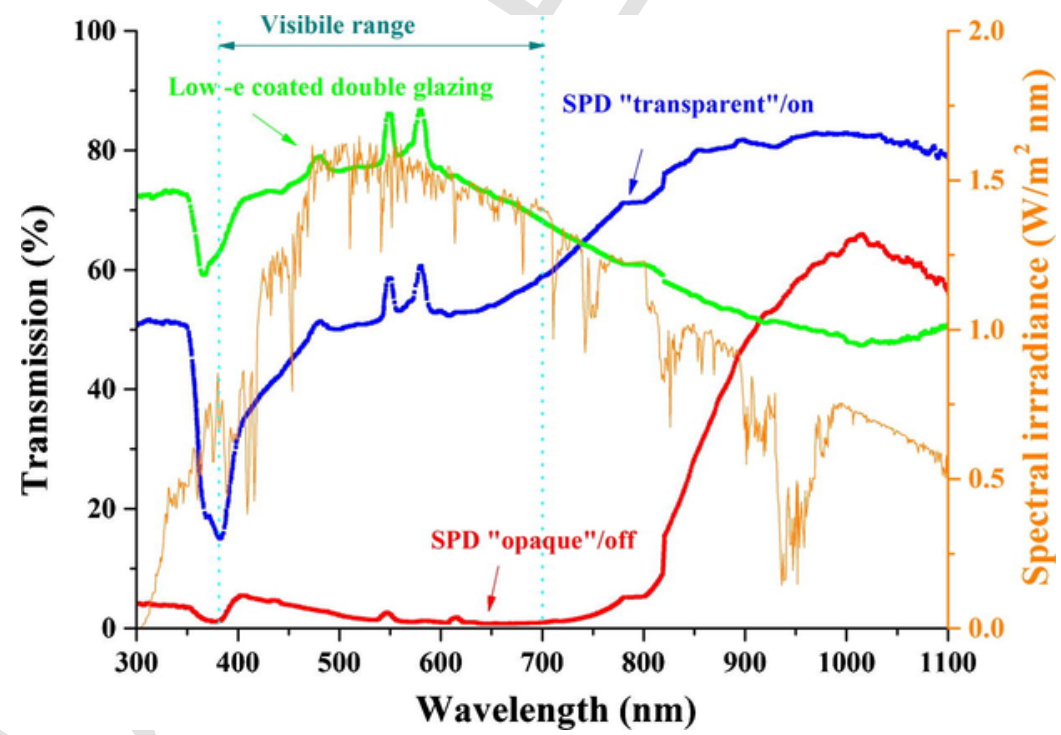

Fig. 4. Visible and NIR transmission of SPD glazing opaque and transparent state and low-e coated double-glazing. Transmission was compared with AM 1.5 solar spectrum. 
Table 1

Details of glazing

\begin{tabular}{|c|c|c|c|c|c|}
\hline & Applied voltage (V) & Average solar transparency (\%) in visible wavelength & Absorption (\%) & Dimensions $(\mathrm{m} \times \mathrm{m})$ & Supplier \\
\hline Double glazing & Not applicable & 78 & 17 & $0.21 \times 0.28$ & Pilkington \\
\hline SPD "opaque" state & 0 & 5 & 9 & $0.21 \times 0.28$ & Smart glass international \\
\hline SPD "transparent" state & 110 & 55 & 4 & $0.21 \times 0.28$ & \\
\hline
\end{tabular}

$$
\begin{aligned}
S E_{\text {spd }}= & \left(I_{\text {beam }, h}+I_{d i f, h} A_{i}\right) \tau_{d i r} r_{b} \\
& +I_{d i f, h}\left(1+A_{i}\right) \tau_{d i f, h} \frac{(1+\cos \beta)}{2} \\
& +I_{\text {global }} \rho_{g} \tau_{g} \frac{(1-\cos \beta)}{2}
\end{aligned}
$$

where $A_{i}$ is anisotropy index that indicates atmospheric transmittance due to beam solar radiation given by

$$
A_{i}=\frac{I_{\text {beam }, h}}{I_{\text {extra }}}
$$
(10)

The dynamic solar heat gain coefficient was calculated from Eq

$$
S H G C=\frac{S E_{\text {spd }}}{I_{\text {ver, }, \text { lobal }}}
$$

\subsection{Overall heat transfer coefficients}

To calculate overall heat transfer coefficient, following assumptions were made:

- Measurements were made while the vacuum glazing was in thermal steady state.

- Ground reflected solar radiation was assumed to be zero.

- The test cell was made of homogeneous highly insulating materials.

Energy balance equation using heat exchanger can be written as Eq. (11)

$$
Q_{\text {in }}=Q_{g}+Q_{\text {hexchanger }}+Q_{\text {loss }}
$$

where

$$
Q_{\text {in }}=I(t) A_{g} \tau_{v}(\theta) \alpha
$$

Heat loss through the glazing is given by

$$
Q_{g}=A_{g} U_{g}\left(T_{t c, \text { in }}-T_{t c, \text { out }}\right)
$$

Heat removal from the test cell

$$
Q_{\text {hexchanger }}=\dot{m}_{\text {water }} c_{\text {water }}\left(T_{w o}-T_{w i}\right)
$$

$\dot{m}_{\text {water }}=\rho_{\text {water }} A v_{\text {water }}$

$\Delta T=\left(T_{\text {outw }}-T_{\text {inw }}\right)$

Heat losses through the wall is represented by

$$
Q_{\text {loss }}=Q_{\text {wall }}=(U A)_{\text {wall }}\left(T_{t c, \text { in }}-T_{t c, \text { out }}\right)
$$

$(U A)_{\text {wall }}=\left[\frac{1}{h_{0}}+\frac{L_{p l}}{K_{p l}}+\frac{L_{w d}}{K_{w d}}+\frac{1}{h_{i}}\right]^{-1} \times A_{\text {wall }}$

The convective heat transfer coefficient [88] between ambient air and outer glazing surface is calculated with the local wind speed $V_{\text {wind }}$

$$
\begin{aligned}
& h_{i}=2.0+3 \mathrm{~V}_{\text {wind }} \\
& h_{0}=5.7+8.8 \mathrm{~V}_{\text {wind }}
\end{aligned}
$$

Overall heat transfer coefficient $U_{g}$ for glazing with heat removal was calculated from

$$
U_{g}=\frac{Q_{\text {in }}-Q_{\text {hexchanger }}-Q_{\text {loss }}}{A_{g}\left(T_{t c, \text { in }}-T_{t c, \text { out }}\right)}
$$

\section{Results and discussion}

\subsection{Measurement without heat removal from the test cell}

Fig. 5 shows the solar energy transmitted through the SPD in "transparent" and "opaque" states and through double-glazing for a typical sunny day in Dublin. The maximum energy transmitted through the double-glazing, SPD "transparent" and SPD "opaque" nearly at $12: 00$ noon were $520 \mathrm{~W} / \mathrm{m}^{2}, 410 \mathrm{~W} / \mathrm{m}^{2}, 50 \mathrm{~W} / \mathrm{m}^{2}$ respectively. Fig. 6 shows the changing solar heat gain coefficients (SHGC) for incidence angle for double-glazing, SPD "transparent" and "opaque" state. Variation of glazing transmission is shown in the figure, which changed with incidence angle. Direct transmission changed with incidence angle. SHGC changed for SPD "transparent" from 0.38 to 0.08 . For SPD "opaque" state SHGC was 0.05 at mid-day period.

Fig. 7 indicates the test cell internal temperature of SPD glazing "transparent" and "opaque" states and double-glazing, which was recorded for typical Dublin sunny day. From clearness index and 


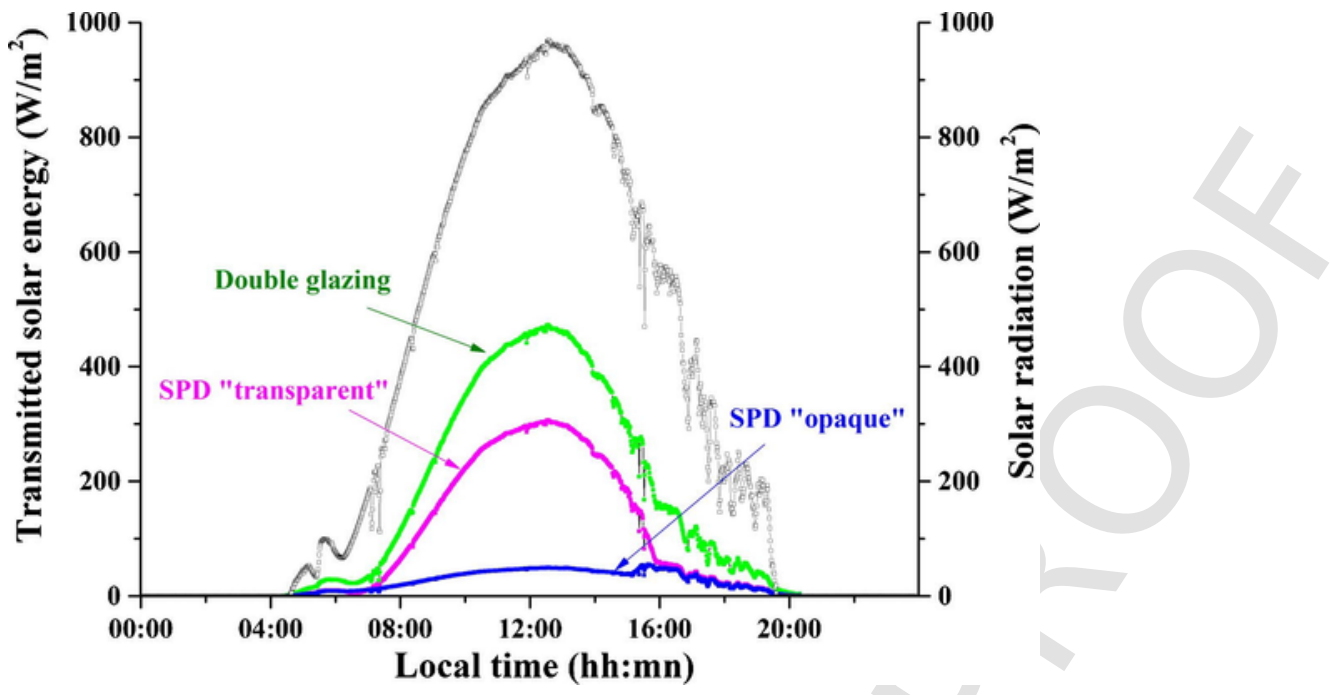

Fig. 5. Solar energy transmitted through SPD "transparent", "opaque" and double-glazing.

anisotropic index, it can be seen that influence of direct solar radiation was high until 15:00 h. Maximum temperature for these three cases was $39^{\circ} \mathrm{C}, 35^{\circ} \mathrm{C}$ and $44{ }^{\circ} \mathrm{C}$ respectively. Ambient temperature was maximum $22{ }^{\circ} \mathrm{C}$ with temperature swing of $11^{\circ} \mathrm{C}$ between $04: 00 \mathrm{~h}$ and 12:00 $\mathrm{h}$. This rise of indoor temperature was higher than the standard $22{ }^{\circ} \mathrm{C}$ comfortable room temperature. Test cell temperature for SPD glazing "transparent" and "opaque" state increased at $1.8^{\circ} \mathrm{C} / \mathrm{h}$ and $1.4{ }^{\circ} \mathrm{C} / \mathrm{h}$ respectively. For double-glazing, internal temperature increased at $2{ }^{\circ} \mathrm{C} / \mathrm{h}$ while the ambient temperature increased at $1.0{ }^{\circ} \mathrm{C} / \mathrm{h}$. Maximum temperature rise was $11 \%$ and $15 \%$ less for SPD "transparent" and "opaque" state compared to double-glazing. Maximum temperature and thermal swing from 04:00 $\mathrm{h}$ to 14:00 $\mathrm{h}$ are listed in Table 2.

\subsection{Measurement with heat removal from the test cell}

Fig. 8 illustrates the temperature difference of water in and out of the test cell for double-glazing SPD "transparent" and "opaque" states. The water mass flow rate was constant $0.016 \mathrm{~kg} / \mathrm{s}$ for all three cases. Maximum temperature difference of water inlet and outlet for double-glazing was $3{ }^{\circ} \mathrm{C}$ while for SPD "transparent" was $2.4{ }^{\circ} \mathrm{C}$ and "opaque" was $0.8^{\circ} \mathrm{C}$.

Total extracted heat from SPD "transparent", double and SPD "opaque" states were $10.38 \mathrm{~kW} \mathrm{h,} 10.64 \mathrm{~kW} \mathrm{h,} 4.02 \mathrm{~kW}$ h for a sunny day while mass flow rate of water was $0.016 \mathrm{~kg} / \mathrm{s}$ as shown in Fig. 9. It indicates that to keep the room at lower temperature in summer SPD opaque condition is more useful as $62 \%$ less heat had to be extracted from test cell and 2\% while SPD transparent compared to double-glazing. Thus, SPD "opaque" state reduces the cooling load. The daily energy saving requirement to ensure an indoor temperature close to comfort temperature $\left(21-25^{\circ} \mathrm{C}\right)$ is $6 \mathrm{~kW} \mathrm{~h}$ for SPD "opaque" and $0.26 \mathrm{~kW}$ h for SPD "transparent" compared to double glazing.

Fig. 10 shows the test cell internal temperature after constant water mass flow rate $0.016 \mathrm{~kg} / \mathrm{s}$ inside the heat exchanger. Double-glazing maximum temperature reached $29^{\circ} \mathrm{C}$ while SPD "transparent and "opaque" were $25^{\circ} \mathrm{C}$ and $22{ }^{\circ} \mathrm{C}$. Test cell internal temperatures for double, SPD "transparent" and SPD "opaque" state reduced to $32 \%$, $34 \%$ and $37 \%$ respectively compare to no heat exchanger case (Fig. 7). Table 3 presents the physical parameters, which were used for the calculation of overall heat transfer coefficient.
Diurnal variation of overall heat transfer coefficient was calculated using Eq. (19) are shown for Double-glazing, SPD "opaque" and "transparent" state were $2.3 \mathrm{~W} / \mathrm{m}^{2} \mathrm{~K}, 5.02 \mathrm{~W} / \mathrm{m}^{2} \mathrm{~K}$ and $5.2 \mathrm{~W} / \mathrm{m}^{2} \mathrm{~K}$ respectively as shown in Figs. 11-13.

SPD glazing average $U$-value from our previous investigation was $5.9 \mathrm{~W} / \mathrm{m}^{2} \mathrm{~K}$ [32]. In this work, variation of average $U$-value was due to the heat removal effect from the test cell.

From experimental results, following advantages of SPD switchable glazing are found;

- Variable SHGC - Buildings experience diurnal solar gain due to diurnal variation of solar radiation. Variable transparency of switchable SPD glazing has potential to control this variable solar gain. Two different types of SHGC coefficients are possible from this SPD glazing, which has immense impact on building application. Presence of variable SHGC can enhance the occupant comfort by changing the states of the glazing.

Cooling load reduction potential - Transmission change of SPD glazing from transparent to opaque state has potential to reduce cooling load. Up to $6 \mathrm{~kW}$ h reduction of electricity demand reduction was possible from $0.343 \mathrm{~m}^{3}$ test cell by changing the SPD glazing from transparent to opaque state.

High $U$-value and variable SHGC - High $U$-value and variable SHGC make this glazing a suitable applicant for summer time where discomfort caused by solar gain will be reduced by changing SPD transparent to opaque and high $U$-value offers high heat losses from inside room to outside ambient.

High $U$-value indicates SPD glazing behaviour as a single glazing with controllable switchable transparency, which offers variable SHGC and cooling load reduction. These unique properties make it a potential candidate for retrofit or new building application.

\section{Conclusions}

Cooling load reduction potential of suspended particle device (SPD) glazing from "transparent" state to "opaque" state was investigated using an outdoor test cell integrated with one copper coil water flow heat exchanger. Without heat removal, maximum test cell temperatures were $35^{\circ} \mathrm{C}$ and $39^{\circ} \mathrm{C}$ for SPD glazing "opaque" and "transparent" states. Variable solar heat gain coefficient from 0.05 to 

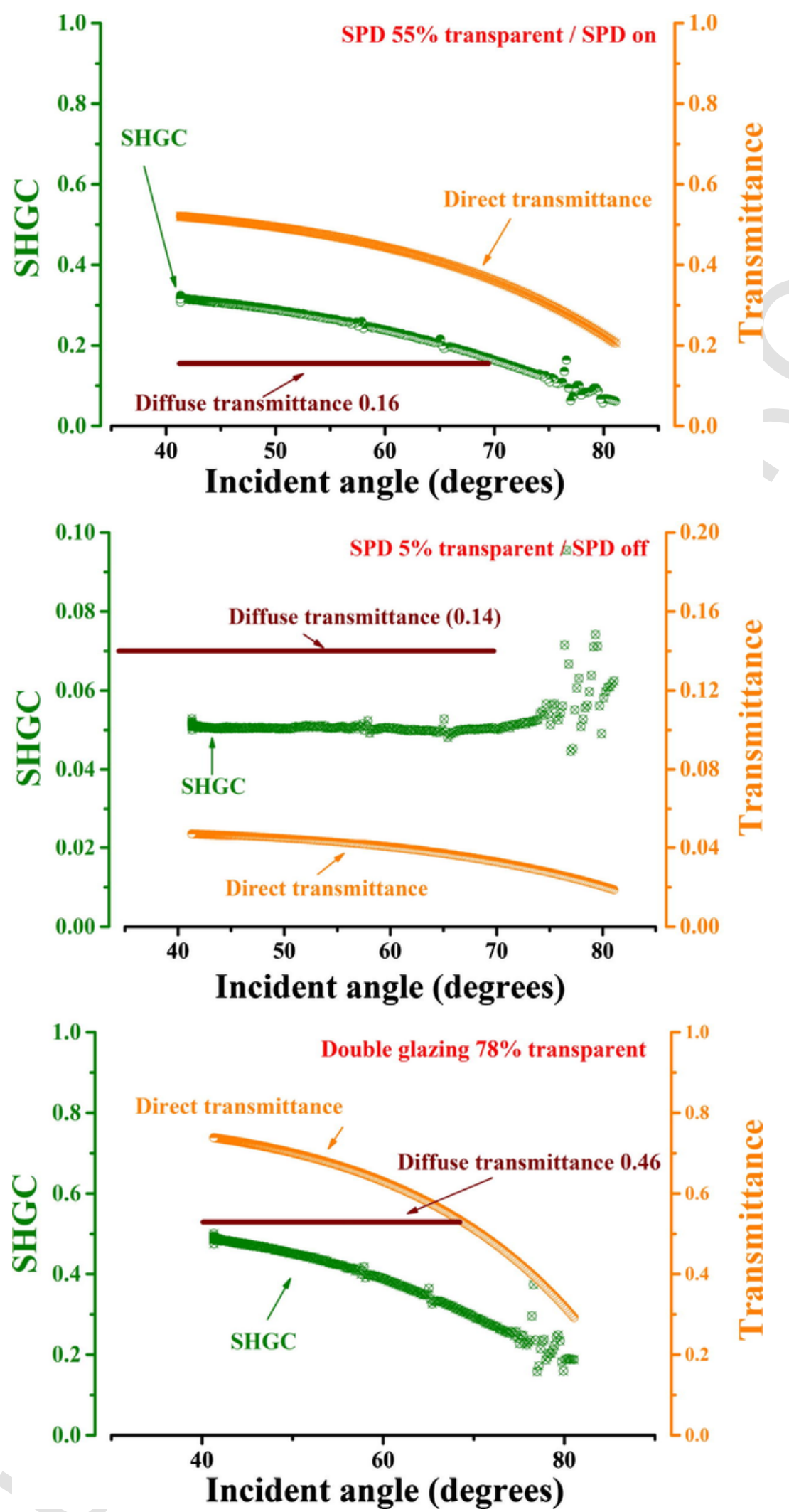

Fig. 6. Change of SHGC and transmittance of SPD glazing for its transparent (55\%) and opaque (5\%) states and double-glazing (78\% transparent) with incident angle.

0.38 was achieved using SPD switchable glazing. A $0.016 \mathrm{~kg} / \mathrm{s}$ constant water mass flow rate through heat exchanger reduced the inter- nal test cell temperatures to $25^{\circ} \mathrm{C}$ and $22{ }^{\circ} \mathrm{C}$ for SPD "transparent" and SPD "opaque". For the particular test cell, reduction of cooling 


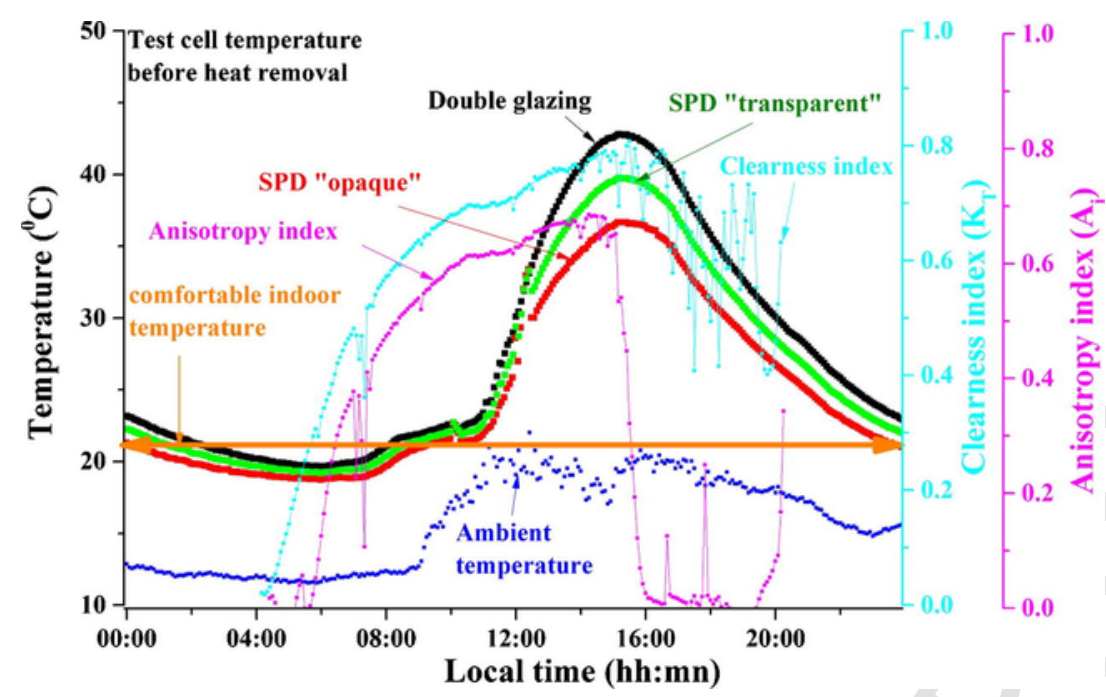

Fig. 7. Test cell internal temperature of double-glazing, SPD "transparent" and "opaque" states before using the water flow for a typical sunny day in Dublin.

Table 2

Test cell temperature for different glazing.

\begin{tabular}{|c|c|c|c|}
\hline & & $\begin{array}{l}\text { Maximum internal } \\
\text { temperature }\left({ }^{\circ} \mathrm{C}\right)\end{array}$ & $\begin{array}{l}\text { Internal temperature swing }\left({ }^{\circ} \mathrm{C} \text { ) }\right. \\
\text { (between } 04: 00 \mathrm{~h} \text { and } 14: 00 \mathrm{~h} \text { ) }\end{array}$ \\
\hline \multirow{4}{*}{ Glazing } & $\begin{array}{l}\text { SPD } \\
\text { "transparent" } \\
\text { test cell }\end{array}$ & 39 & 18 \\
\hline & $\begin{array}{l}\text { SPD "opaque" } \\
\text { test cell }\end{array}$ & 35 & 15 \\
\hline & $\begin{array}{l}\text { Double } \\
\text { glazing test } \\
\text { cell }\end{array}$ & 44 & 20 \\
\hline & Ambient & 22 & 10 \\
\hline
\end{tabular}

load when comparing the SPD in the transparent with the SPD in the opaque state was $6 \mathrm{kWh}$. Overall heat transfer coefficient of SPD glazing when "transparent" and when "opaque" state were $5.2 \mathrm{~W} /$ $\mathrm{m}^{2} \mathrm{~K}$ and $5.02 \mathrm{~W} / \mathrm{m}^{2} \mathrm{~K}$ respectively. Variable switchability of SPD glazing is advantageous for building application as cooling demand of building also vary throughout the day.

\section{Uncited references}

$[60,61]$.

\section{Acknowledgements}

The research work was supported by the Graduate Research Education Programme of the Higher Education Authority, Ireland.

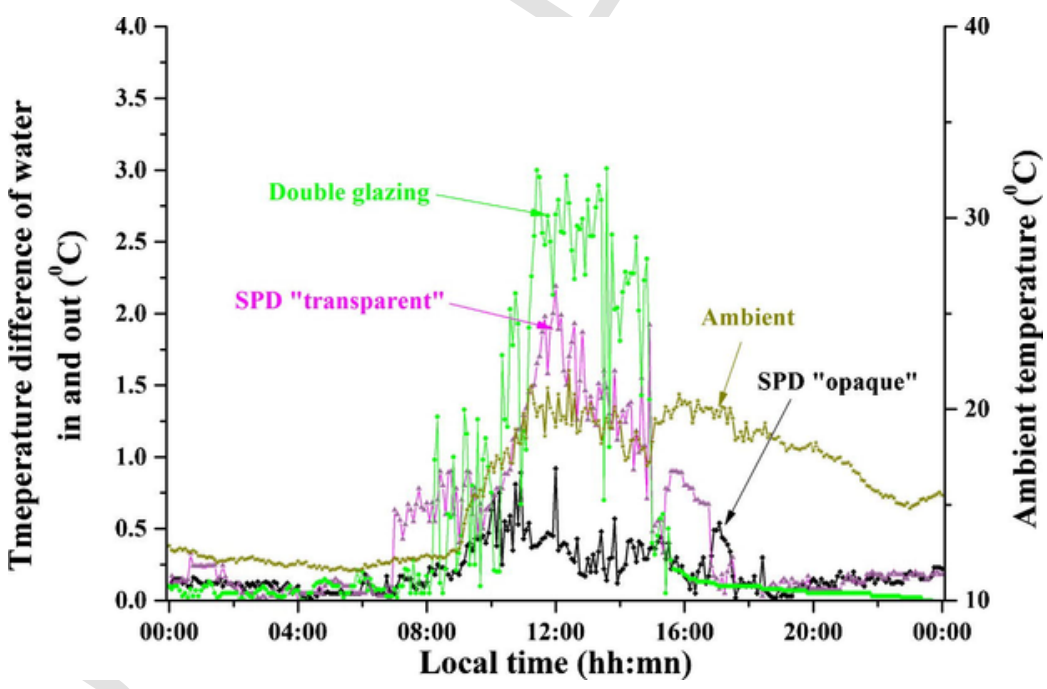

Fig. 8. Temperature difference of water flowing inside the test cell for double-glazing, SPD "transparent" and "opaque" states at constant water mass flow rate $0.016 \mathrm{~kg} / \mathrm{s}$. 


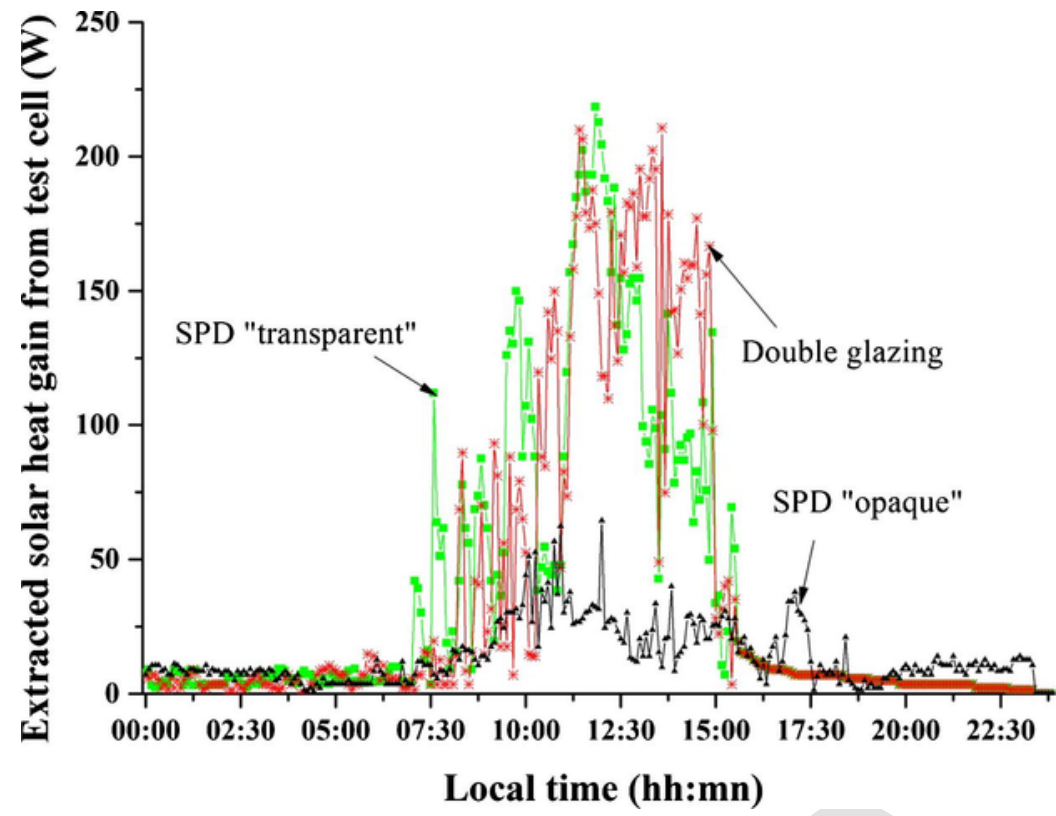

Fig. 9. Heat extracted from SPD "transparent", SPD "opaque" and double-glazing test cell at constant $0.016 \mathrm{~kg} / \mathrm{s}$ water mass flow rate.

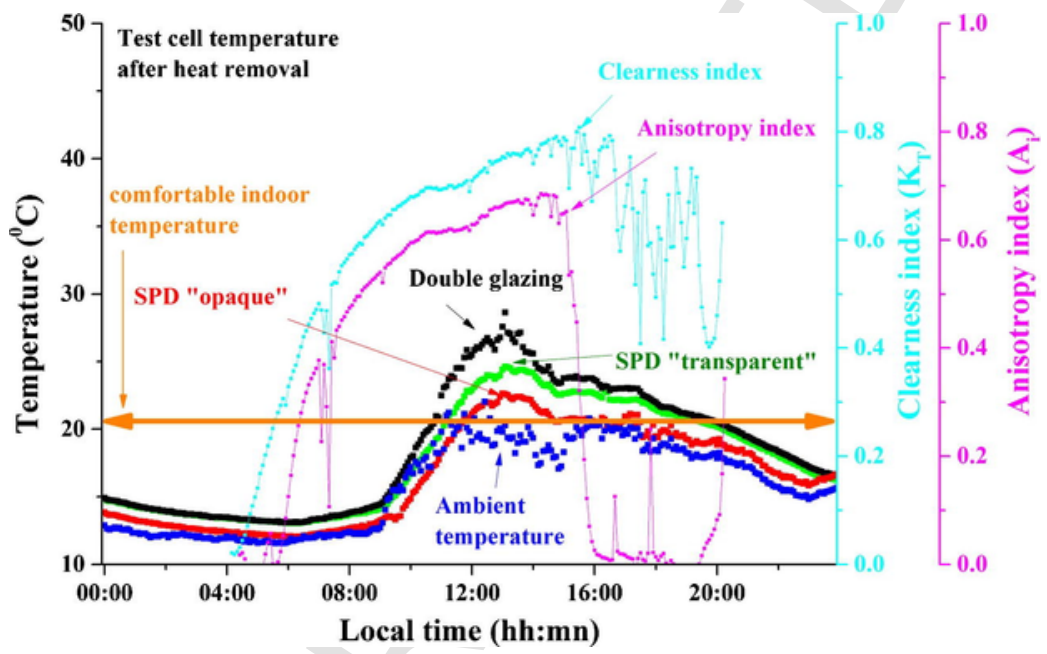

Fig. 10. Test cell internal temperature of double-glazing, SPD "transparent" and "opaque" state at $0.016 \mathrm{~kg} / \mathrm{s}$ water mass flow rate 
Table 3

Parameters used for the calculations.

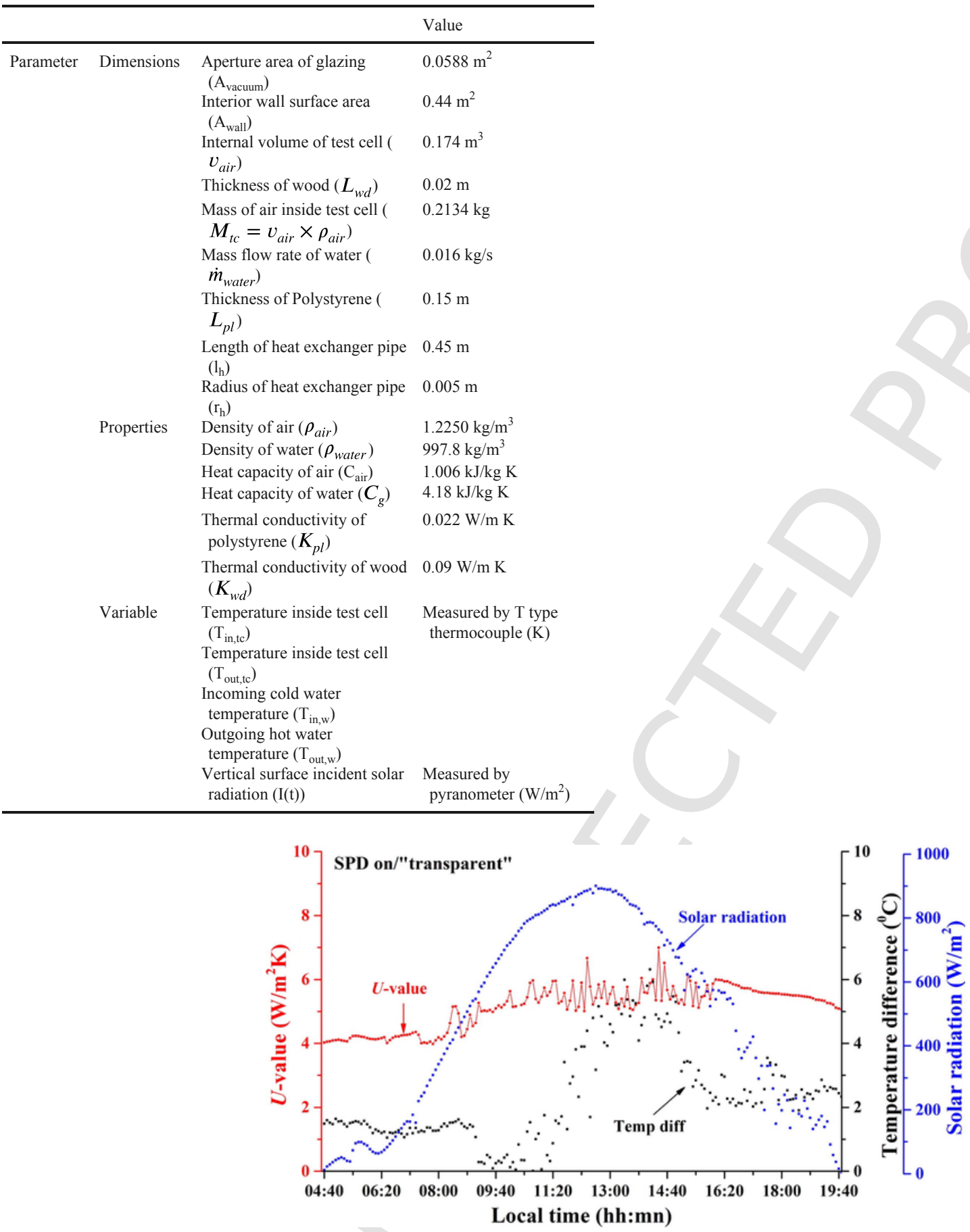

Fig. 11. Diurnal variation of overall heat transfer coefficient ( $U$-value) for SPD glazing "transparent" state. 


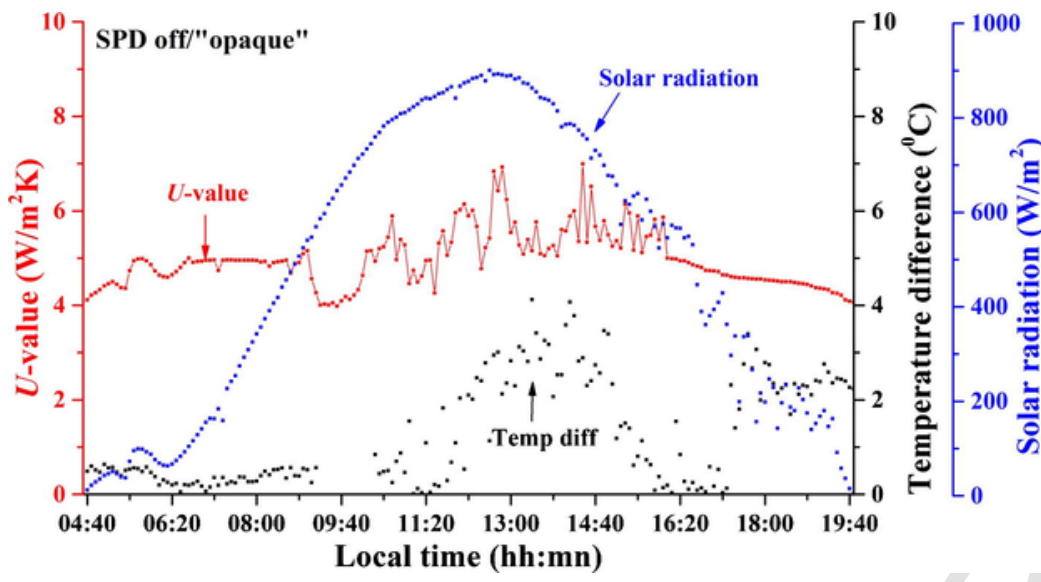

Fig. 12. Diurnal variation of overall heat transfer coefficient ( $U$-value) for SPD glazing "opaque" state.

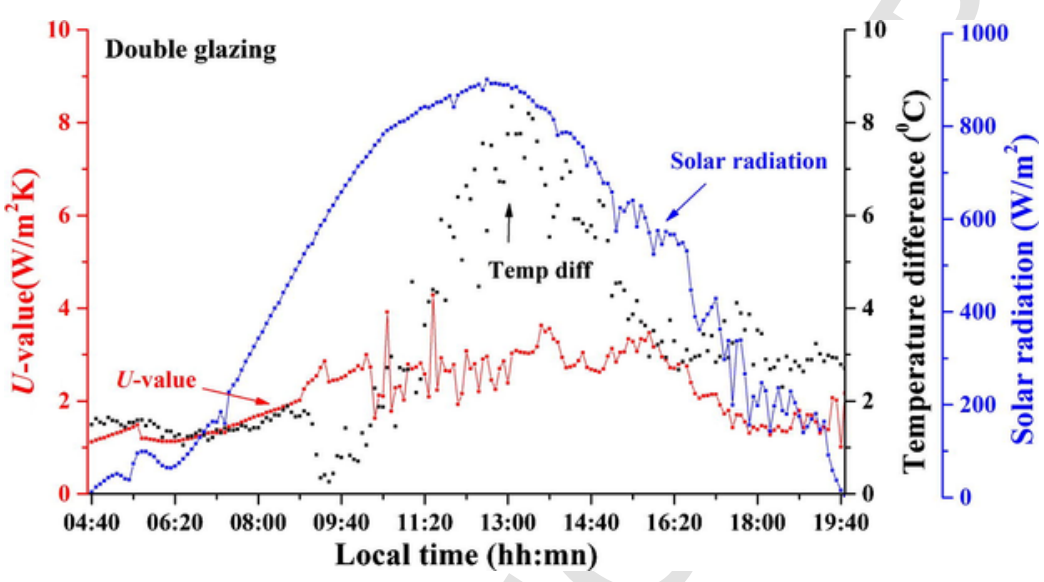

Fig. 13. Diurnal variation of overall heat transfer coefficient ( $U$-value) for double-glazing.

\section{References}

[1] J. Lei, J. Yang, E.H. Yang, Energy performance of building envelopes integrated with phase change materials for cooling load reduction in tropical Singapore, Appl Energy 162 (2016) 207-217.

[2] A. Waqas, Z. Ud Din, Phase change material (PCM) storage for free cooling of buildings-a review, Renew Sustain Energy Rev 18 (2013) 607-625.

[3] G. Evola, L. Marletta, The solar response factor to calculate the cooling load induced by solar gains, Appl Energy 160 (2015) 431-441.

[4] B. Norton, Harnessing solar heat, Springer, Dordrecht, Netherlands, 2014.

[5] T. Silva, R. Vicente, F. Rodrigues, Literature review on the use of phase change materials in glazing and shading solutions, Renew Sustain Energy Rev 53 (2016) 515-535.

[6] S.A. Al-Sanea, M.F. Zedan, S.N. Al-Hussain, Effect of thermal mass on performance of insulated building walls and the concept of energy savings potential, Appl Energy 89 (2012) 430-442.

[7] G. Leftheriotis, P. Yianoulis, Characterisation and stability of low-emittance multiple coatings for glazing applications, Sol Energy Mater Sol Cells 58 (1999) 185-197.

[8] C.G. Granqvist, Transparent conductors as solar energy materials: a panoramic review, Sol Energy Mater Sol Cells 91 (2007) 1529-1598.

[9] K.A.R. Ismail, J.R. Henriquez, Two-dimensional model for the double glass naturally ventilated window, Int J Heat Mass Transf 48 (2005) 461-475.

[10] T.P. Wang, L.B. Wang, A steady heat transfer model of hollow double glazing under entire wave length heat radiation, Energy Build 81 (2014) 72-83.

[11] P.H. Baker, M. McEvoy, Test cell analysis of the use of a supply air window as a passive solar component, Sol Energy 69 (2000) 113-130.

[12] M.E. McEvoy, R.G. Southall, P.H. Baker, Test cell evaluation of supply air windows to characterise their optimum performance and its verification by the use of modelling techniques, Energy Build 35 (2003) 1009-1020.
[13] R.G. Southall, M.E. McEvoy, Investigations into the functioning of a supply air window in relation to solar energy as determined by experiment and simulation, Sol Energy 80 (2006) 512-523.

[14] T.T. Chow, C. Li, Z. Lin, The function of solar absorbing window as water-heating device, Build Environ 46 (2011) 955-960.

[15] T.T. Chow, C. Li, Z. Lin, Thermal characteristics of water-flow double-pane window, Int J Therm Sci 50 (2011) 140-148.

[16] T.T. Chow, C. Li, Z. Lin, Innovative solar windows for cooling-demand climate, Sol Energy Mater Sol Cells 94 (2010) 212-220.

[17] T.T. Chow, C. Li, Liquid-filled solar glazing design for buoyant water-flow, Build Environ 60 (2013) 45-55.

[18] A. Qahtan, S.P. Rao, N. Keumala, The effectiveness of the sustainable flowing water film in improving the solar-optical properties of glazing in the tropics, Energy Build 77 (2014) 247-255.

[19] K.A.R. Ismail, J.R. Henriquez, Simplified model for a ventilated glass window under forced airflow conditions, Appl Therm Eng 26 (2006) 295-302.

[20] T.G. Lopez, C.G. Molina, Influence of double glazing with a circulating water chamber on the thermal energy savings in buildings, Energy Build 56 (2013) $56-65$.

[21] T.G. Lopez, C.G. Molina, Environmental, economic and energy analysis of double glazing with a circulating water chamber in residential buildings, Appl Energy 101 (2013) 572-581.

[22] C.G. Granqvist, Electrochromic tungsten oxide films: review of progress 1993-1998, Sol Energy Mater Sol Cells 60 (2000) 201-262.

[23] C.G. Granqvist, E. Avendan, A. Azens, Electrochromic coatings and devices: survey of some recent advances, Thin Solid Films 442 (2003) 201-211.

[24] C.G. Granqvist, Electrochromic devices, J Eur Ceram Soc 25 (2005) 2907-2912.

[25] C.G. Granqvist, S. Green, G.A. Niklasson, N.R. Mlyuka, S.V. Kræmer, P. Georén, Advances in chromogenic materials and devices, Thin Solid Films 518 (2010) 3046-3053.

[26] C.M. Lampert, Optical switching technology for glazings, Thin Solid Films 236 (1993) 6-13. 
[27] D.J. Gardiner, S.M. Morris, H.J. Coles, High-efficiency multistable switchable glazing using smectic A liquid crystals, Sol Energy Mater Sol Cells 93 (2009) 301-306.

[28] D. Cupelli, F.P. Nicoletta, S. Manfredi, M. Vivacqua, P. Formoso, G. DeFilpo, et al., Self-adjusting smart windows based on polymer-dispersed liquid crystals, Sol Energy Mater Sol Cells 93 (2009) 2008-2012.

[29] D. Barrios, R. Vergaz, J.M.S.N. Pena, C.G. Granqvist, G.A. Niklasson, Toward a quantitative model for suspended particle devices: optical scattering and absorption coefficients, Sol Energy Mater Sol Cells 111 (2013) 115-122.

[30] D. Barrios, R. Vergaz, J.M.S.N. Pena, B.G. Cámara, C.G. Granqvist, G.A. Niklasson, Simulation of the thickness dependence of the optical properties of suspended particle devices, Sol Energy Mater Sol Cells 143 (2015) 613-622.

[31] R. Vergaz, J.M.S.N. Pena, D. Barrios, C. Vazquez, P.C. Lallana, Modelling and electro-optical testing of suspended particle devices, Sol Energy Mater Sol Cells 92 (2008) 1483-1487.

[32] A. Ghosh, B. Norton, A. Duffy, Measured overall heat transfer coefficient of a suspended particle device switchable glazing, Appl Energy 159 (2015) 362-369.

[33] A. Ghosh, B. Norton, A. Duffy, Measured thermal performance of a combined suspended particle switchable device evacuated glazing, Appl Energy 169 (2016) 469-480.

[34] A. Ghosh, B. Norton, A. Duffy, Daylighting performance and glare calculation of a suspended particle device switchable glazing, Sol Energy 132 (2016) $114-128$.

[35] A. Ghosh, B. Norton, A. Duffy, First outdoor characterisation of a PV powered suspended particle device switchable glazing, Sol Energy Mater Sol Cells 157 (2016) 1-9.

[36] A. Ghosh, B. Norton, A. Duffy, Measured thermal \& daylight performance of an evacuated glazing using an outdoor test cell, Appl Energy 177 (2016) 196-203.

[37] A. Georg, W. Graf, R. Neumann, V. Wittwer, Mechanism of the gasochromic coloration of porous $\mathrm{WO}_{3}$ films, Solid State Ionics 127 (2000) 319-328.

[38] A. Georg, W. Graf, R. Neumann, V. Wittwer, The role of water in gasochromic $\mathrm{WO}_{3}$ films, Thin Solid Films 384 (2001) 269-275.

[39] C.C. Chan, W.C. Hsu, C.C. Chang, C.S. Hsu, Preparation and characterization of gasochromic $\mathrm{Pt} / \mathrm{WO}_{3}$ hydrogen sensor by using the Taguchi design method, Sensors Actuat B: Chem 145 (2010) 691-697.

[40] K. Yoshimura, Y. Yamada, S. Bao, K. Tajima, M. Okada, Preparation and characterization of gasochromic switchable-mirror window with practical size, Sol Energy Mater Sol Cells 93 (2009) 2138-2142.

[41] V. Witter, M. Datz, J. Ell, A. Georg, W. Graf, G. Walze, Gasochromic windows, Sol Energy Mater Sol Cells 84 (2004) 305-314

[42] H. Ye, X. Meng, B. Xu, Theoretical discussions of perfect window, ideal near infrared solar spectrum regulating window and current thermochromic window, Energy Build 49 (2012) 164-172.

[43] L. Long, H. Ye, Discussion of the performance improvement of thermochromic smart glazing applied in passive buildings, Sol Energy 107 (2014) 236-244.

[44] M. Saeli, C. Piccirillo, I.P. Parkin, R. Binions, I. Ridley, Energy modelling studies of thermochromic glazing, Energy Build 42 (2010) 1666-1673.

[45] H. Watanabe, Intelligent window using a hydrogel layer for energy efficiency, Sol Energy Mater Sol Cells 54 (1998) 203-211.

[46] P. Nitz, H. Hartwig, Solar control with thermotropic layers, Sol Energy 79 (2005) 573-582.

[47] F. Goia, Thermo-physical behaviour and energy performance assessment of PCM glazing system configurations: a numerical analysis, Front Archit Res 1 (2012) 341-347.

[48] F. Goia, M. Zinzi, E. Carnielo, V. Serra, Spectral and angular solar properties of a PCM-filled double glazing unit, Energy Build 87 (2015) 302-312.

[49] F. Goia, M. Perino, V. Serra, Experimental analysis of the energy performance of a full-scale PCM glazing prototype, Sol Energy 100 (2014) 217-233.

[50] F. Goia, M. Perino, V. Serra, Improving thermal comfort conditions by means of PCM glazing systems, Energy Build 60 (2013) 442-452.

[51] H. Manz, P.W. Egolf, P. Suter, A. Goetzberger, TIM-PCM External wall system for solar space heating and daylighting, Sol Energy 61 (1997) 369-379.

[52] D. Zhou, C.Y. Zhao, Y. Tian, Review on thermal energy storage with phase change materials (PCMs) in building applications, Appl Energy 92 (2012) 593-605.

[53] X. Jin, M.A. Medina, X. Zhang, On the importance of the location of PCMs in building walls for enhanced thermal performance, Appl Energy 106 (2013) $72-78$.

[54] K.A.R. Ismail, J.R. Henríquez, Parametric study on composite and PCM glass system, Energy Convers Manage 43 (2002) 973-993.

[55] K.A.R. Ismail, C.T. Salinas, J.R. Henríquez, Comparison between PCM filled glass windows and absorbing gas-filled windows, Energy Build 40 (2008) 710-719

[56] D.R. Rosseinsky, R.J. Mortimer, Electrochromic systems and the prospects for devices, Adv Mater 13 (2001) 783-793.

[57] E.S. Lee, D.L. DiBartolomeo, F.M. Rubinstein, S.E. Selkowitz, Low-cost networking for dynamic window systems, Energy Build 36 (2004) 503-513.

[58] C.G. Granqvist, Oxide electrochromics: an introduction to devices and materials, Sol Energy Mater Sol Cells 99 (2012) 1-13.
[59] S.K. Deb, S.H. Lee, C.E. Tracy, J.R. Pitts, B.A. Gregg, H.M. Branz, Standalone photovoltaic powered electrochromic smart window, Electrochim Acta 46 (2001) 2125-2130.

[60] J. Nagai, G.D. McMeeking, Y. Saitoh, Durability of electrochromic glazing, Sol Energy Mater Sol Cells 56 (1999) 309-319.

[61] C.G. Granqvist, Handbook of inorganic electrochromic materials, Elsevier, Amsterdam, 1995.

[62] S. Park, J.W. Hong, Polymer dispersed liquid crystal film for variable-transparency glazing, Thin Solid Films 517 (2009) 3183-3186.

[63] S. Papaefthimiou, G. Leftheriotis, P. Yianoulis, T.J. Hyde, P.C. Eames, Y. Fang, et al., Development of electrochromic evacuated advanced glazing, Energy Build 38 (2006) 1455-1467.

[64] C.M. Lampert, Smart switchable glazing for solar energy and daylight control, Sol Energy Mater Sol Cells 52 (1998) 207-221.

[65] D.P. Grimmer, R.D. McFarland, J.D. Balcomb, Initial experimental tests on the use of small passive-solar test-boxes to model the thermal performance of passively solar-heated building designs, Sol Energy 22 (1979) 351-354.

[66] Klems JH, Selkowitz S, Horowitz S. A mobile facility for measuring net energy performance of windows and skylights. In: 3rd international symposium on energy conservation in the built environment, Dublin, Ireland, march 30-April 1; 1982

[67] Klems J, Keller H. Measurement of single and double glazing thermal performance under realistics condition using the mobile window thermal test (MoWiTT) facility. In: ASME solar energy division conference, Honolulu, HI March 22-27; 1987.

[68] P. Robinson, J. Littler, Advanced glazing: outdoor test room measurements, performance prediction and building thermal simulation, Build Environ 28 (1993) $145-152$.

[69] C.W. Leung, S.D. Probert, Heat-exchanger design: optimal length of an array of uniformly-spaced vertical rectangular fins protruding upwards from a horizontal base, Appl Energy 30 (1988) 29-35.

[70] C.W. Leung, S.D. Probert, Heat-exchanger performance: effect of orientation, Appl Energy 33 (1989) 235-252.

[71] M.K. Ghosal, G.N. Tiwari, N.S.L. Srivastava, Thermal modeling of a greenhouse with an integrated earth to air heat exchanger: an experimental validation, Energy Build 36 (2004) 219-227.

[72] Prabhakant, G.N. Tiwari, Analytical study of heat exchanger design, Energy Convers Manage 32 (1991) 403-408.

[73] Y.P. Yadav, G.N. Tiwari, S. Sucheta, Analytical study of a ground collector integrated with heat exchanger, Energy Convers Manage 29 (1989) 245-251.

[74] M.O. Akpomiemie, R. Smith, Retrofit of heat exchanger networks with heat transfer enhancement based on an area ratio approach, Appl Energy 165 (2016) $22-35$.

[75] S. Nayak, G.N. Tiwari, Energy metrics of photovoltaic/thermal and earth air heat exchanger integrated greenhouse for different climatic conditions of India, Appl Energy 87 (2010) 2984-2993.

[76] G.N. Tiwari, S.A. Lawrence, A transient analysis of a closed loop solar thermosyphon water heater with heat exchangers, Energy Convers Manage 31 (1991) 505-508.

[77] S.A. Tabssum, B. Norton, S.D. Probert, Heat removal from a solar energy collector with a heat- pipe absorber, Sol Wind Technol 5 (1988) 141-145.

[78] B. Norton, S.D. Probert, Solar-energy stimulated, open-looped thermosyphonic air heaters, Appl Energy 17 (1984) 217-234.

[79] B. Norton, S.D. Probert, Natural circulation solar energy stimulated systems for heating water, Appl Energy 11 (1982) 167-196.

[80] B. Norton, P.A. Hobson, S.D. Probert, Heat removal from a triangular finned flat-plate solar-energy collector, Appl Energy 34 (1989) 47-55.

[81] S.A. Lawrence, G.N. Tiwari, Theoretical evaluation of solar distillation under natural circulation with heat exchanger, Energy Convers Manage 30 (1990) 205-213.

[82] S. Agrawal, G.N. Tiwari, Energy and exergy analysis of hybrid micro-channel photovoltaic thermal module, Sol Energy 85 (2011) 356-370.

[83] Shyam, G.N. Tiwari, O. Fischer, R.K. Mishra, I.M. Al-Helald, Performance evaluation of N-photovoltaic thermal (PVT) water collectors partially covered by photovoltaic module connected in series: an experimental study, Sol Energy 134 (2016) 302-313.

[84] S. Lee, S. Kim, S. Kim, Y. Park, J. Park, Experimental research on performance of the solar heat gain (SHG) insulation panel, Build Environ 41 (2006) 336-342.

[85] Y.B. Band, Light and matter: electromagnetism, optics, spectroscopy and lasers, John Wiley \& Sons, 2010.

[86] P.A. Waide, B. Norton, Variation of insolation transmission with glazing plane position and sky conditions, ASME J Sol Energy Eng 125 (2003) 182-189.

[87] M.J. Brandemuehl, W.A. Beckman, Transmission of diffuse radiation through CPC and flat-plate collector glazings, Sol Energy 24 (1980) 511-513.

[88] J.A. Duffie, W.A. Beckman, Solar engineering of thermal processes, 4th ed., Wiley, New York, 2013 